\title{
Deafness in TR $\beta$ Mutants Is Caused by Malformation of the Tectorial Membrane
}

\author{
Harald Winter, ${ }^{1,2 \star}$ Lukas Rüttiger, ${ }^{1,2 *}$ Marcus Müller, ${ }^{1,3}$ Stephanie Kuhn, ${ }^{1,4}$ Niels Brandt, ${ }^{1,4}$ Ulrike Zimmermann, ${ }^{1,2}$ \\ Bernhard Hirt, ${ }^{1,3,5}$ Andreas Bress, ${ }^{1,6}$ Matthias Sausbier, ${ }^{7}$ Aude Conscience, ${ }^{8,9}$ Frederic Flamant, ${ }^{8}$ Yong Tian, ${ }^{10}$ Jian Zuo, ${ }^{10}$ \\ Markus Pfister, ${ }^{1,6}$ Peter Ruth, ${ }^{7}$ Hubert Löwenheim, ${ }^{1,3}$ Jacques Samarut, ${ }^{8}$ Jutta Engel, ${ }^{1,4}$ and Marlies Knipper ${ }^{1,2}$ \\ ${ }^{1}$ Department of Otorhinolaryngology, Tübingen Hearing Research Center, ${ }^{2}$ Molecular Neurobiology and Cell Biology of the Inner Ear, ${ }^{3}$ Molecular Otology, \\ ${ }^{4}$ Institute of Physiology II, ${ }^{5}$ Institute of Anatomy, ${ }^{6}$ Hereditary Hearing Loss, and 7 Institute of Pharmacy, Department of Pharmacology and Toxicology, \\ University of Tübingen, 72076 Tübingen, Germany, ${ }^{8}$ Institut de Génomique Fonctionnelle, Ecole Normale Supérieure de Lyon, 69364 Lyon, France, \\ ${ }^{9}$ Monash Immunology and Stem Cell Laboratories, Monash University, Victoria 3800, Australia, and ${ }^{10}$ Department of Developmental Neurobiology, St. \\ Jude Children's Research Hospital, Memphis, Tennessee 38105
}

Thyroid hormone receptor $\beta(\operatorname{TR} \beta)$ dysfunction leads to deafness in humans and mice. Deafness in TR $\beta^{-1-}$ mutant mice has been attributed to TR $\beta$-mediated control of voltage- and $\mathrm{Ca}^{2+}$-activated $\mathrm{K}^{+}$(BK) channel expression in inner hair cells (IHCs). However, normal hearing in young constitutive $\mathrm{BK} \alpha^{-l-}$ mutants contradicts this hypothesis. Here, we show that mice with hair cell-specific deletion of TR $\beta$ after postnatal day 11 (P11) have a delay in $\mathrm{BK} \alpha$ expression but normal hearing, indicating that the origin of hearing loss in TR $\beta^{-I-}$ mutant mice manifested before P11. Analyzing the phenotype of IHCs in constitutive TR $\beta^{-1-}$ mice, we found normal $\mathrm{Ca}^{2+}$ current amplitudes, exocytosis, and shape of compound action potential waveforms. In contrast, reduced distortion product otoacoustic emissions and cochlear microphonics associated with an abnormal structure of the tectorial membrane and enhanced tectorin levels suggest that disturbed mechanical performance is the primary cause of deafness resulting from TR $\beta$ deficiency.

Key words: hearing; TR $\beta$; BK; conditional knock-out mice; tectorin; exocytosis

\section{Introduction}

Thyroid hormone $(\mathrm{TH})$ and its receptors are essential for the development of hearing as congenital thyroid disorders or iodine deficiency can cause deafness (Forrest, 1996). TH receptors (TR) are ligand-dependent transcription factors encoded by the related $\operatorname{TR} \alpha$ and TR $\beta$ genes (Sap et al., 1986; Weinberger et al., 1986). TR $\alpha 1$ and TR $\beta$ are expressed during embryonic and postnatal development of the cochlea (Bradley et al., 1994), indicating that the cochlea is a direct site of T3 action (Knipper et al., 2001).

Genetic ablation of TR $\beta$ in mice severely impairs auditoryevoked brainstem responses (Forrest et al., 1996), whereas mice with $\mathrm{TR} \alpha$ deletion exhibit normal hearing (Ng et al., 2001). Moreover, the resistance to thyroid hormone (RTH) syndrome in humans is associated with $\operatorname{TR} \beta$ mutations and can present with mild to profound hearing impairment (for review, see Weiss and Refetoff, 2000; Refetoff and Dumitrescu, 2007).

Since cochlear malformations were not reported in constitu-

Received July 28, 2008; revised 0ct. 27, 2008; accepted Dec. 16, 2008.

This work was supported by Deutsche Forschungsgemeinschaft Grants DFG Kni316/4-1 and DFG Ru571/4-1, the Graduate Program (University of Tübingen), The American Lebanese Syrian Associated Charities, National Institutes of Health Grants CA21765, DC05168, DC008800, and DC06471, the Hartwell Foundation, and the Thyssen Foundation. We thank Drs. Susanne Feil and Robert Feil, University of Tübingen, Interfakultäres Institut für Biochemie, for the supply of ROSA26R mice, and Karin Rohbock, Iris Köpschall, and Sylvia Kasperek for excellent technical assistance.

*H.W. and L.R. contributed equally to this work.

Correspondence should be addressed to Dr. Marlies Knipper, Hans-Nasen-Ohren-Klinik, Hörforschungszentrum, Elfriede-Aulhorn-Strasse 5, 72076 Tübingen, Germany. E-mail: marlies.knipper@uni-tuebingen.de.

D01:10.1523/JNEUROSCI.3557-08.2009

Copyright $\odot 2009$ Society for Neuroscience $\quad$ 0270-6474/09/292581-07\$15.00/0 tive TR $\beta^{-l-}$ mice (Forrest et al., 1996), their deafness was attributed to impaired functional rather than morphological maturation (Rüsch et al., 1998). A severe retardation of the expression of the inner hair cell (IHC) fast-activating potassium current termed $I_{\mathrm{K}, \mathrm{f}}$ (Dulon et al., 1995; Kros et al., 1998) was observed in $\mathrm{TR} \beta^{-1-}$ mice (Rüsch et al., 1998). Consequently, inappropriate maturation of auditory brainstem neurons that extract timing information was suggested as a possible reason for deafness (Rüsch et al., 1998). In contrast to the suggested necessity of BK channels during IHC development (Kros et al., 1998), germline deletion of $B K \alpha$, the pore-forming subunit (KCNMA1) of the BK channel, resulted in normal hearing (Rüttiger et al., 2004; Pyott et al., 2007).

We compared the cochlear and hearing phenotype of TR $\beta$ mutants with either germline deletion $\left(\mathrm{TR} \beta^{-1-}\right)$ or postnatal deletion of TR $\beta$ restricted to hair cells $\left(\mathrm{HC}-\mathrm{TR} \beta^{-1-}\right)$. Analyses of both mouse lines exclude that delayed $I_{\mathrm{K}, \mathrm{f}}$ expression or retrocochlear defects cause hearing loss in $\mathrm{TR} \beta^{-1-}$ mice. Instead, our results suggest that malformation of the tectorial membrane (TM) results in reduced mechanical performance of the cochlea and deafness.

\section{Materials and Methods}

Generation of hair cell-specific TR $\beta$-deficient mice. The TR $\beta^{\text {lox }}(\mathrm{TR} \beta \mathrm{L} 2)$ allele was constructed by homologous recombination, introducing two loxP sites $5^{\prime}$ and $3^{\prime}$ to exon 5. A FRTNeoFRT cassette was also introduced downstream of the $3^{\prime}$ LoxP sequence for in vitro drug selection and later eliminated by FLP (flippase)-mediated recombination, leaving only one FRT (flippase recombination target) sequence. We verified by PCR and 
Southern blotting that Cre (cyclization recombination) recombinasemediated recombination results in the deletion of exon 5 , both in embryonic stem cells and in mice. Exon 5 deletion introduces a frame shift, so that the deleted locus has the potential to encode only truncated products, whose homology extend to the DNA binding domain (amino acid 178 of TR $\beta 1$ ). TR $\beta$ L2/L2 mice (mixed C57BL/6J/129/SV background) were crossed with constitutive TR $\beta^{-1-}$ (C57BL/6J/SV129 background) (Forrest et al., 1996) mice to generate TR $\beta$ L2/-mutants. TR $\beta^{-/-}$mice were crossed with Prestin-Cre transgenic mice, termed PCre (SV129/ FVB background) (Tian et al., 2004) to obtain heterozygous Prestin-Cre transgenic $\operatorname{TR} \beta^{+/-}$mice $\left(\mathrm{TR} \beta^{+/-} \mathrm{PCre}\right) . \operatorname{TR} \beta$ L $2 /$-mutants were crossed with $\operatorname{TR} \beta^{+/-}$PCre mice to generate $\operatorname{TR} \beta \mathrm{L} 2 /+$, used as controls (HC-TR $\beta$-Ctr), TR $\beta^{-1-}$, used as constitutive knock-out controls, and Prestin-Cre transgenic TR $\beta$ L2/-mutants, displaying hair cell-specific deletion of TR $\beta$ (HC-TR $\beta^{-1-}$ ). Offspring was genotyped by RT-PCR, and animals of respective genotypes were repetitively tested for their hearing thresholds at the age of 1-4 months as indicated. As control animals for the TR $\beta^{-1-}$ mice we used either wild-type $\left(\operatorname{TR} \beta^{+/+}\right)$, heterozygous TR $\beta^{+/-}$(Forrest et al., 1996), or TR $\beta^{+/-}$TR $\alpha 1^{+/-}$mice (Rusch et al., 2001), all termed TR $\beta$-Ctr.

Care and use of the animals and the experimental protocol were reviewed and approved by the animal welfare commissioner and the regional board for scientific animal experiments in Tübingen.

Immunohistochemistry and histological staining. Procedure of standard immunohistochemistry is described by Knipper et al. (2000). For anatomical studies cochleae were isolated, fixed in paraformaldehyde, decalcified in EDTA and postfixed in osmium tetroxide. After dehydration in solutions of ethanol at increasing concentrations cochleae were embedded in epoxy resin. Serial sections of $10 \mu \mathrm{m}$ were counterstained with toluidine blue. Thickness (height), width, and cross-sectional area of the tectorial membrane were measured according to (Keiler and Richter, 2001). Measurements were done by using the software Cell ${ }^{\mathrm{F}}$ from SoftImaging Systems (Olympus) and compared by paired two sample Student's $t$ test.

Antibodies. The $\alpha$-tectorin and $\beta$-tectorin antibodies were generated by immunizing one rabbit in each case (Charles River) with synthetic peptides corresponding to conserved regions of mouse $\alpha$ - and $\beta$-tectorin. For further information, see supplemental material, available at www.jneurosci.org. In addition, we used rabbit polyclonal anti-BK $\alpha$ (Alomone Laboratories) and rabbit polyclonal anti-KCNQ4 (Rüttiger et al., 2004; Winter et al., 2006).

Electrophysiological recordings. Whole-cell voltage-activated $\mathrm{K}^{+}$currents and voltage-activated capacitance changes were recorded in IHCs using acute explants of the organ of Corti (apical turn) as described previously (Brandt et al., 2007).

Hearing measurements. All physiological recordings were performed under anesthesia in a soundproof chamber (IAC) as described previously (Müller et al., 1997; Rüttiger et al., 2004). For further information, see supplemental material, available at www.jneurosci.org.

Western blotting. Western blot analysis of cochlear tissue of TR $\beta$-Ctr and $\operatorname{TR} \beta^{-1-}$ mice was performed as described previously (Schug et al., 2006). For quantification of $\alpha$-tectorin (Santa Cruz, s.c.-18035, 1:400) and $\beta$-tectorin (see above, 1:3000) levels in TR $\beta^{-1-}$ mice, the $\alpha$-respectively the $\beta$-tectorin Western blot was performed simultaneously with the ezrin antibody (Dianova, 1:750). Densitometric analysis was performed using the Soft Imaging System Cell ${ }^{\mathrm{F}}$ from Olympus. The intensities were normalized to the level of the codetected ezrin as an internal control (Knipper et al., 2001). Control and knock-out mice were compared and data expressed as mean percentage of control (set at 100\%) \pm SD. Western blots were performed on three different sets of animals with one repetition.

\section{Results}

Hair cell-specific TR $\beta$-deficient mice $\left(\mathrm{HC}-\mathrm{TR} \boldsymbol{\beta}^{-/-}\right)$have normal hearing despite retarded expression of BK channels First, we aimed to define the time period when deafness manifests in TR $\beta$ mutants by comparing hearing function and physiology of conditional and constitutive TR $\beta$ knock-out

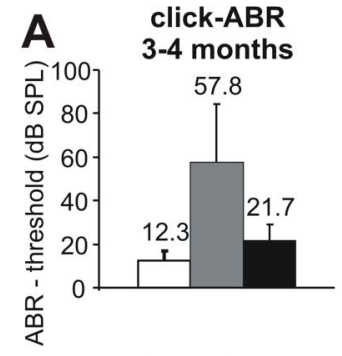

- HC-TR $\beta-C t r, n=8$

- $\operatorname{TR} \beta(-/-), \mathrm{n}=6$

- $\operatorname{HC}-\operatorname{TR} \beta(-/-), \mathrm{n}=18$
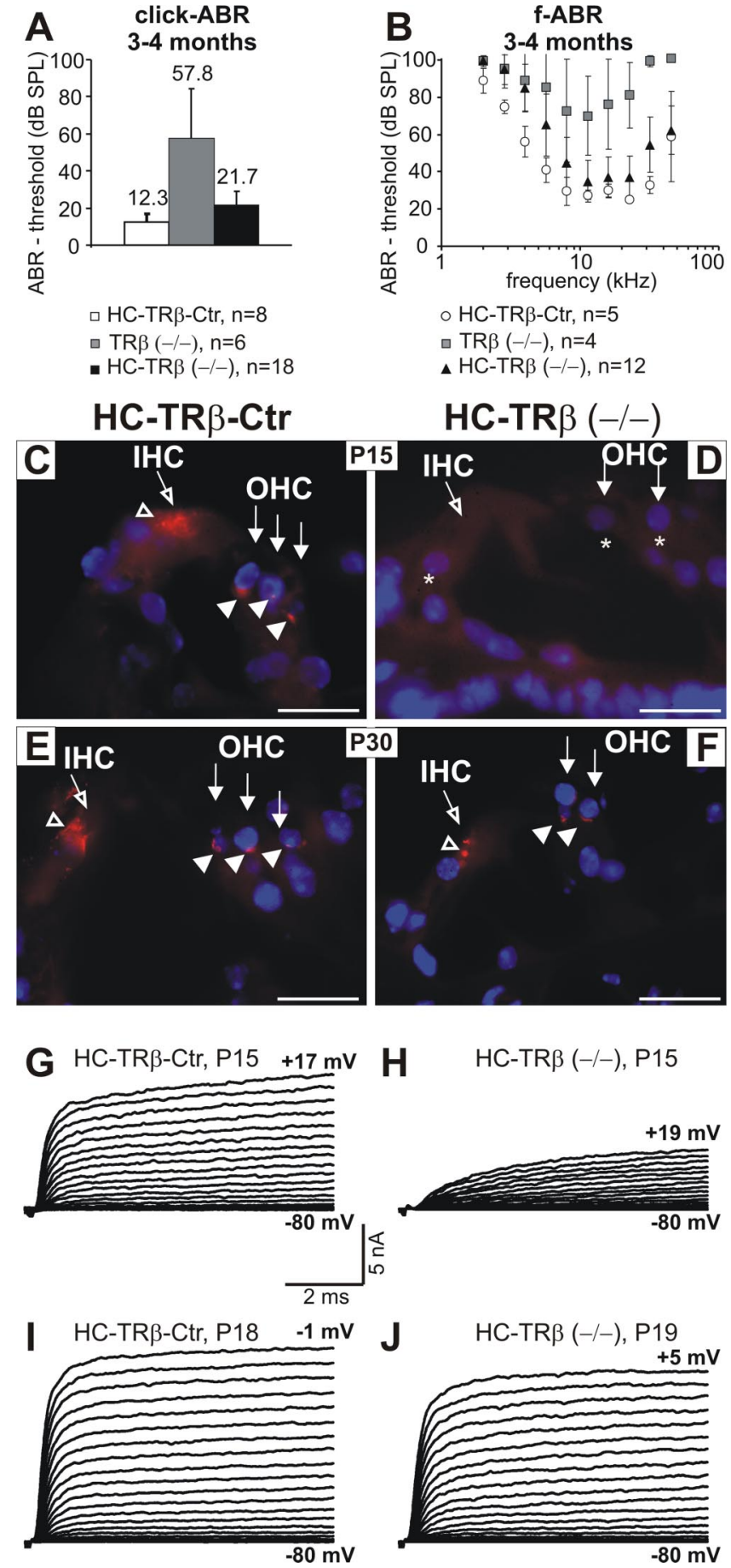

Figure 1. $\boldsymbol{A}, \boldsymbol{B}, \mathrm{ABR}$ measurements in $\mathrm{HC}-\mathrm{TR} \beta-\mathrm{Ctr}, \mathrm{HC}-\mathrm{TR} \beta^{-1-}$, and $\operatorname{TR} \beta^{-1-}$ mice. At 3-4 months, TR $\beta^{-1-}$ mice show a significant elevation of click-evoked ABR thresholds $(\boldsymbol{A})$. Frequency-specific $A B R$ thresholds of $\mathrm{HC}-\mathrm{TR} \beta^{-1-}$ mice show a significant threshold elevation at frequencies $<8 \mathrm{kHz}(\boldsymbol{B}) .(\mathbf{C}, \boldsymbol{F}, \mathrm{BK} \alpha$ expression (red, arrowheads) in HC-TR $\beta$-Ctr and HC$\operatorname{TR} \beta^{-1-}$ mice at indicated ages. Note lack of BK $\alpha$ expression in IHCs and OHCs of HC-TR $\beta^{-1-}$ mice at P15. Nuclei are stained in blue with DAPI. Scale bars, $20 \mu \mathrm{m}$. G-J, Typical IHC voltageactivated $\mathrm{K}^{+}$currents in HC-TR $\beta$-Ctr mice at P15 (G) and P18 (I) compared with IHCs of HC-TR $\beta^{-l-}$ mice $(\boldsymbol{H}, \boldsymbol{J})$.

mice (Fig. 1). The Prestin-Cre transgenic mouse strain (Tian et al., 2004) was used to generate TR $\beta$ mutant mice carrying a hair cell-specific gene deletion (see Materials and Methods). Onset of Cre activity was demonstrated by LacZ expression after Cre-mediated recombination using X-gal staining. For 

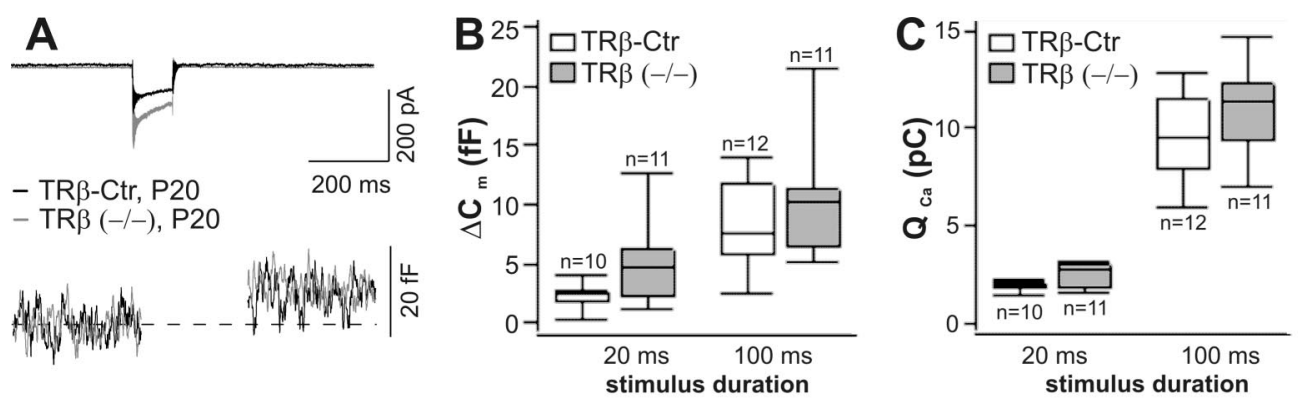

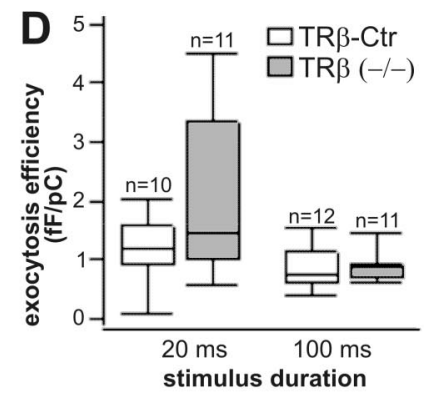

G CAP and SP response

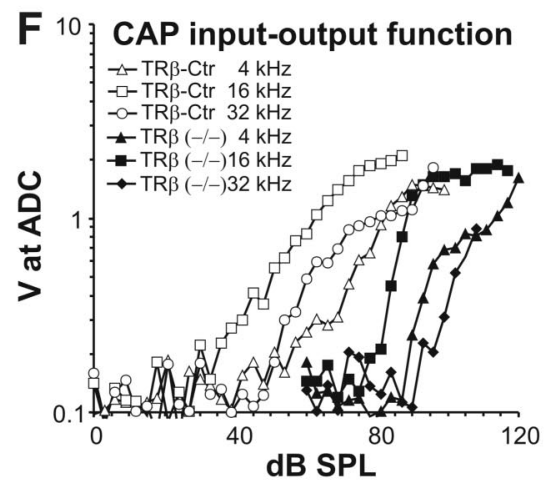

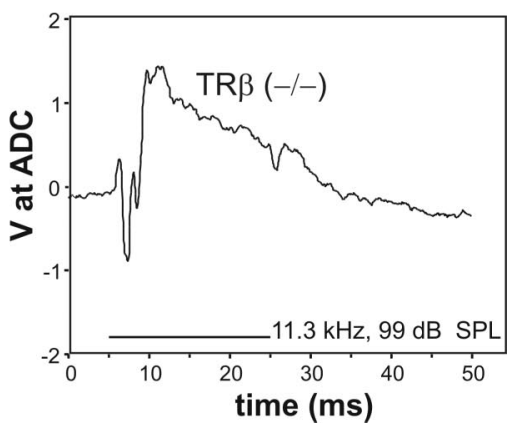

E

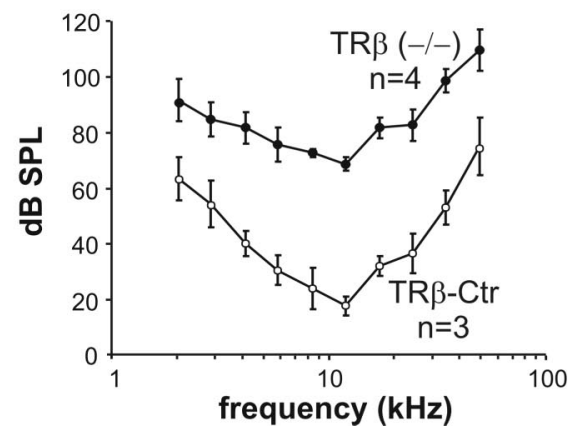

CAP threshold

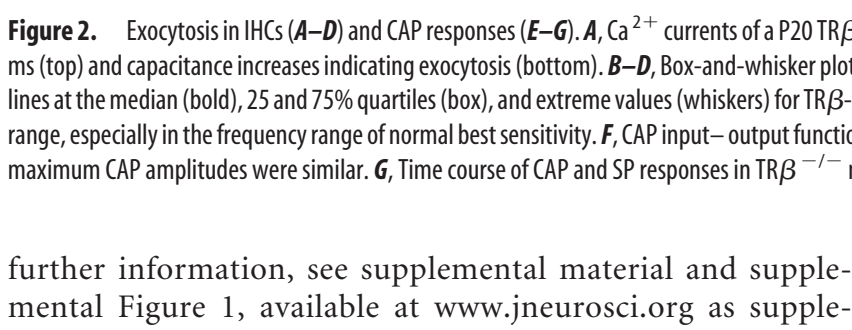
mental material. Auditory brainstem response (ABR) thresholds for click auditory stimuli (Fig. $1 A$ ) confirmed elevated hearing thresholds (Forrest et al., 1996) in 3- to 4-month-old $\mathrm{TR} \beta^{-l-}$ mice $[57.8 \pm 26.6 \mathrm{~dB}$ sound pressure level (SPL), $n=$ 6], whereas hair cell-specific $\mathrm{HC}-\mathrm{TR} \beta^{-/-}$mice had hearing thresholds of $21.7 \pm 11.2 \mathrm{~dB}$ SPL $(n=18)$ that were only slightly different from that of HC-TR $\beta$-Ctr animals (12.3 \pm $4.5 \mathrm{~dB}$ SPL, $n=8)$. Frequency-dependent ABR measurements $\left(\right.$ Fig. $1 B$ ) revealed a severe threshold shift in $\mathrm{HC}-\mathrm{TR} \beta^{-1-}$ mice, whereas hair cell-specific TR $\beta$ deletion in IHCs and outer hair cells (OHCs) from postnatal day 12 (P12) onwards may have affected hair cells only in apical cochlear turns (Fig. $1 B)$. Nevertheless, similar to previous studies, $\mathrm{BK} \alpha$ expression was delayed in IHCs of HC-TR $\beta^{-/-}$mice (Fig. $1 C-J$ ). At P15, when $\mathrm{BK} \alpha$ was expressed in IHCs and OHCs of HC-TR $\beta$-Ctr mice (Fig. 1C), age-matched HC-TR $\beta^{-1-}$ mice did not show any $\mathrm{BK} \alpha$ protein in IHCs and $\mathrm{OHCs}$ (Fig. $1 D$ ). At P30, however, there was no difference in the $\mathrm{BK} \alpha$ expression of $\mathrm{HC}$ TR $\beta$-Ctr (Fig. $1 E$ ) and HC-TR $\beta^{-/-}$mice (Fig. $1 F$ ). Recording voltage-activated $\mathrm{K}^{+}$currents in IHCs from hearing onset onwards revealed a fast activating $\mathrm{K}^{+}$current component in $\mathrm{HC}-\mathrm{TR} \beta$-Ctr at P15 (Fig. $1 G$ ) indicative of $\mathrm{BK} \alpha$ expression (Kros et al., 1998; Brandt et al., 2007), which was lacking in IHCs of HC-TR $\beta^{-/-}$mice (Fig. $1 H$ ). Four days later, IHC K ${ }^{+}$ currents of a P19 HC-TR $\beta^{-l-}$ mouse (Fig. $1 J$ ) showed increased current amplitudes and accelerated activation kinetics that were comparable with those of the P18 control IHC (Fig. $1 I$ ). These findings indicate that the deafness of $\operatorname{TR} \beta^{-/-} \mathrm{mu}-$ tants is not caused by the lack of $\operatorname{TR} \beta$ function in hair cells after the onset of hearing or by a TR $\beta$-induced delay of BK channel expression. Therefore, we analyzed the physiology of IHCs of constitutive TR $\beta^{-1-}$ mice in more detail.

To test if exocytosis is functional in $\mathrm{TR} \beta^{-1-}$ IHCs, we performed capacitance measurements. Capacitance changes $\left(\Delta C_{\mathrm{m}}\right)$ were recorded in response to voltage steps of 20 and $100 \mathrm{~ms}$ duration from the holding potential $(-80 \mathrm{mV})$ to the potential of maximal $\mathrm{Ca}^{2+}$ influx $(0 \mathrm{mV})$ for P20 TR $\beta$-Ctr and TR $\beta^{-1-}$ mice (Fig. 2A-D). Figure $2 A$ shows example current traces in response to a depolarizing step of $100 \mathrm{~ms}$ duration (top) and the corresponding capacitance changes (bottom) for TR $\beta$-Ctr and $\mathrm{TR} \beta^{-1-}$ mice. Average capacitance changes shown in a box-andwhisker plot (Fig. $2 B$ ) did not reveal significant differences of $\Delta C_{\mathrm{m}}$ between IHCs of TR $\beta$-Ctr and TR $\beta^{-1-}$ mice for both stimulus durations $(p>0.05)$ despite the larger variability of $\Delta C_{\mathrm{m}}$ in $\mathrm{TR} \beta^{-1-}$ mice. Neither the corresponding $\mathrm{Ca}^{2+}$ charge $\left(Q_{\mathrm{Ca}}\right)$ entering the cell during depolarization nor the efficiency of exocytosis, the ratio between $\Delta C_{\mathrm{m}}$ and $Q_{\mathrm{Ca}}$, showed significant differences (Fig. 2C,D) in TR $\beta^{-1-}$ IHCs compared with $\mathrm{TR} \beta$-Ctr IHCs. IHCs typically show an increase in exocytosis efficiency by the end of the third postnatal week (Beutner and Moser, 2001; Johnson et al., 2005), a developmental process controlled by $\mathrm{TH}$ (Brandt et al., 2007). Our results indicate that $\mathrm{TH}$-dependent maturation of exocytosis is not mediated by the $\operatorname{TR} \beta$ receptor (Fig. 2D).

To distinguish if deafness after deletion of TR $\beta$ is of cochlear and/or retrocochlear origin, we measured compound action potentials (CAP). Similar to ABR thresholds (Fig. 1) and findings of Forrest et al. (1996), CAP thresholds were clearly elevated in 3- to 4-month-old $\mathrm{TR} \beta^{-1-}$ mice at all frequencies tested (Fig. 2 E). TR $\beta$-Ctr mice exhibited best thresholds of $\sim 20 \mathrm{~dB}$ SPL at $11.3 \mathrm{kHz}$, whereas in age-matched $\mathrm{TR} \beta^{-1-}$ mice, best thresholds of $70 \mathrm{~dB}$ SPL were found at 11.3 

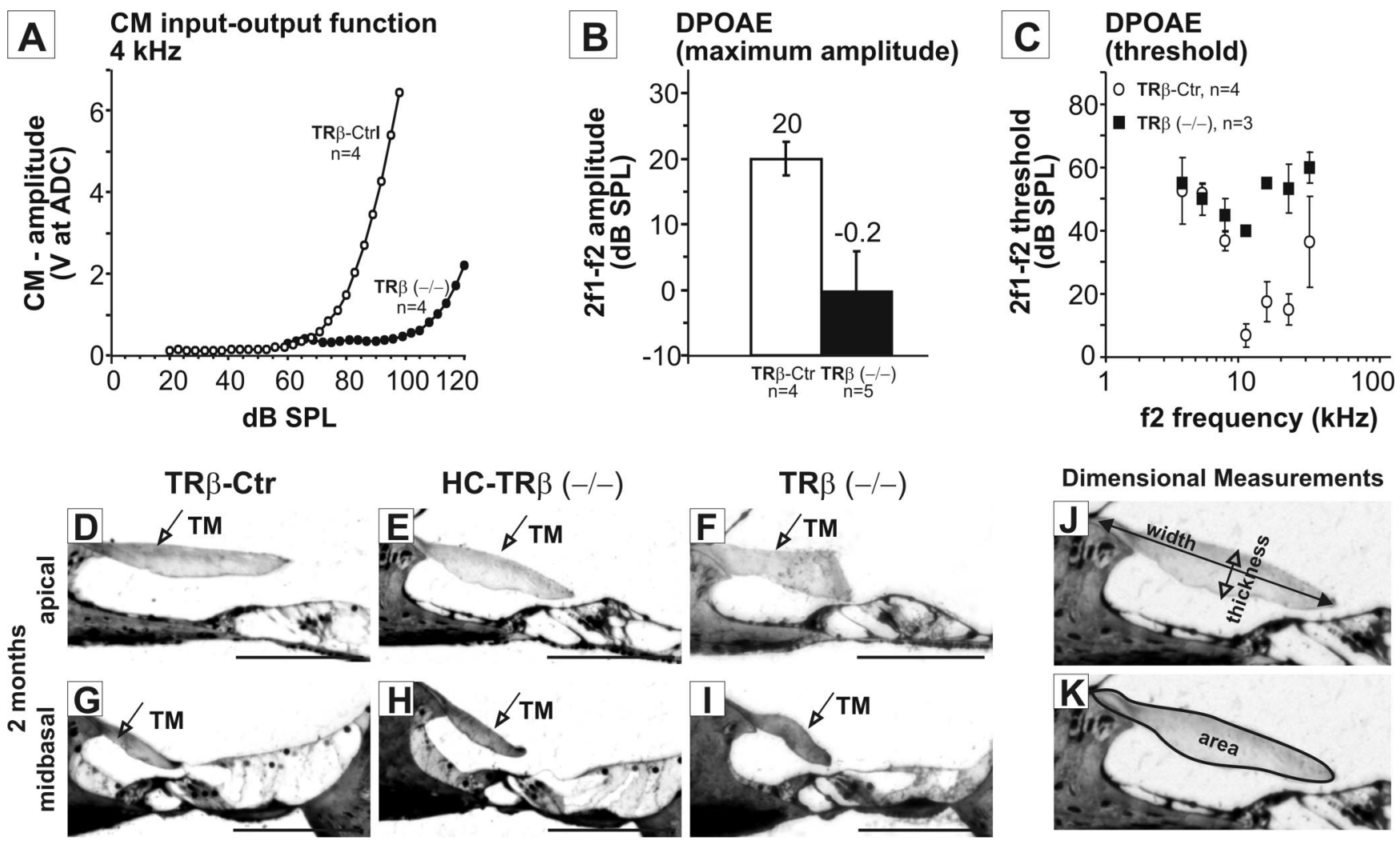

L

\begin{tabular}{|c|c|c|c|c|c|c|c|c|c|}
\hline \multirow[t]{2}{*}{ Genotype } & \multicolumn{3}{|c|}{ Width [um] } & \multicolumn{3}{|c|}{ Thickness $[\mu \mathrm{m}]$} & \multicolumn{3}{|c|}{ Area $\left[\mu \mathrm{m}^{2}\right]$} \\
\hline & apical & medial & midbasal & apical & medial & midbasal & apical & medial & midbasal \\
\hline $\begin{array}{c}\text { TR } \beta \text {-Ctr } \\
\text { (mouse 1) }\end{array}$ & $\begin{array}{c}190.4 \pm 27.0 \\
n=36\end{array}$ & $\begin{array}{c}187.3 \pm 39.0 \\
n=36\end{array}$ & $\begin{array}{c}128.0 \pm 10.3 \\
n=60\end{array}$ & $\begin{array}{c}26.1 \pm 1.2 \\
n=36\end{array}$ & $\begin{array}{c}23.6 \pm 1.6 \\
n=36\end{array}$ & $\begin{array}{c}16.2 \pm 1.0 \\
n=60\end{array}$ & $\begin{array}{c}3288.5 \pm 342.8 \\
n=36\end{array}$ & $\begin{array}{c}2629.5 \pm 524.8 \\
n=36\end{array}$ & $\begin{array}{c}1173.8 \pm 71.1 \\
n=60\end{array}$ \\
\hline $\begin{array}{c}\text { TR } \beta \text {-Ctr } \\
\text { (mouse 2) }\end{array}$ & $\begin{array}{c}179.0 \pm 34.7 \\
n=20\end{array}$ & $\begin{array}{c}162.4 \pm 39.1 \\
n=20\end{array}$ & $\begin{array}{c}117.8 \pm 4.8 \\
n=20\end{array}$ & $\begin{array}{c}23.5 \pm 1.0 \\
n=20\end{array}$ & $\begin{array}{c}21.5 \pm 1.5 \\
n=20\end{array}$ & $\begin{array}{c}15.6 \pm 1.2 \\
n=20\end{array}$ & $\begin{array}{c}2776.6 \pm 410.5 \\
n=20\end{array}$ & $\begin{array}{c}2266.7 \pm 561.8 \\
n=20\end{array}$ & $\begin{array}{c}1047.9 \pm 68.4 \\
n=20\end{array}$ \\
\hline $\begin{array}{l}\text { HC-TR } \beta^{-1-} \\
\text { (mouse 1) }\end{array}$ & $\begin{array}{c}179.9 \pm 7.6 \\
n=27\end{array}$ & $\begin{array}{c}151.5 \pm 14.8 \\
n=27\end{array}$ & $\begin{array}{c}125.8 \pm 6.7 \\
n=27\end{array}$ & $\begin{array}{c}28.8 \pm 1.6 \\
n=27\end{array}$ & $\begin{array}{c}23.5 \pm 1.3 \\
n=27\end{array}$ & $\begin{array}{c}17.1 \pm 0.9 \\
n=27\end{array}$ & $\begin{array}{c}3219.5 \pm 111.1 \\
n=27\end{array}$ & $\begin{array}{c}2269.6 \pm 211.1 \\
n=27\end{array}$ & $\begin{array}{c}1328.4 \pm 75.5 \\
n=27\end{array}$ \\
\hline $\begin{array}{l}\text { HC-TR } \beta^{-1-} \\
\text { (mouse 2) }\end{array}$ & $\begin{array}{c}183.3 \pm 23.6 \\
n=36\end{array}$ & $\begin{array}{c}163.4 \pm 26.1 \\
n=36\end{array}$ & $\begin{array}{c}124.8 \pm 6.7 \\
n=36\end{array}$ & $\begin{array}{c}27.8 \pm 2.2 \\
n=36\end{array}$ & $\begin{array}{c}21.8 \pm 4.0 \\
n=36\end{array}$ & $\begin{array}{c}17.2 \pm 1.6 \\
n=36\end{array}$ & $\begin{array}{c}2940.7 \pm 267.9 \\
n=36\end{array}$ & $\begin{array}{c}2324.1 \pm 360.8 \\
n=36\end{array}$ & $\begin{array}{c}1277.5 \pm 93.1 \\
n=36\end{array}$ \\
\hline $\begin{array}{c}\mathrm{TR} \beta^{-/-} \\
\text {(mouse 1) }\end{array}$ & $\begin{array}{c}176.3 \pm 20.8 \\
n=34\end{array}$ & $\begin{array}{c}145.3 \pm 20.6 \\
n=34\end{array}$ & $\begin{array}{c}129.6 \pm 22-0 \\
n=34\end{array}$ & $\begin{array}{c}34.0 \pm 3.6 \\
n=34\end{array}$ & $\begin{array}{c}31.9 \pm 2.3 \\
n=34\end{array}$ & $\begin{array}{c}21.0 \pm 2.0 \\
n=34\end{array}$ & $\begin{array}{c}4049.6 \pm 585,3 \\
n=34\end{array}$ & $\begin{array}{c}3125.7 \pm 556.3 \\
n=34\end{array}$ & $\begin{array}{c}1599.9 \pm 374.4 \\
n=34\end{array}$ \\
\hline $\begin{array}{c}\mathrm{TR} \beta^{-/-} \\
\text {(mouse 2) }\end{array}$ & $\begin{array}{c}154.8 \pm 12.9 \\
n=27\end{array}$ & $\begin{array}{c}149.4 \pm 14.8 \\
n=27\end{array}$ & $\begin{array}{c}126.1 \pm 7.5 \\
n=27\end{array}$ & $\begin{array}{c}62.3 \pm 3.2 \\
n=27\end{array}$ & $\begin{array}{c}53.7 \pm 2.2 \\
n=27\end{array}$ & $\begin{array}{c}25.6 \pm 2.4 \\
n=27\end{array}$ & $\begin{array}{c}5433.6 \pm 234.7 \\
n=27\end{array}$ & $\begin{array}{c}4189.7 \pm 532.7 \\
n=27\end{array}$ & $\begin{array}{c}1665.3 \pm 167.9 \\
n=27\end{array}$ \\
\hline
\end{tabular}

Mean $\pm \mathrm{SD}$ of $n$ sections of single mice

Figure 3. $A-C, C M$ and DPOAEs of TR $\beta$-Ctr and TR $\beta^{-1-}$ mice. CM are present in both TR $\beta$-Ctr and TR $\beta^{-1-}$ mice, although reduced in TR $\beta^{-1-}$ mice $(\boldsymbol{A})$. DPOAE amplitudes $(\boldsymbol{B})$ and DPOAE thresholds $\left(C\right.$ reveal a loss of active cochlear mechanics in TR $\beta^{-1-}$ mice at frequencies above f1 $=8 \mathrm{kHz}$. D-I, TM structure of TR $\beta$-Ctr, HC-TR $\beta^{-/-}$, and TR $\beta^{-/-}$mice. Cross-sections of epoxy resin-embedded cochleae reveal morphological abnormalities of the TM in TR $\beta^{-1-}$ mice $(\boldsymbol{F}, \boldsymbol{I})$ compared with $\operatorname{TR} \beta$ - $\operatorname{Ctr}(\boldsymbol{D}, \boldsymbol{G})$ and HC-TR $\beta^{-1-}$ mice $(\boldsymbol{E}, \boldsymbol{H})$. Scale bars, $100 \mu \mathrm{m}$. J-L, Dimensional measurements (width, thickness, area) of the TM.

kHz (Fig. 2E). Input-output functions of the CAP responses were shifted to higher SPLs and tended to have steeper slopes than those from TR $\beta$-Ctr mice, yet maximum amplitudes were similar (Fig. 2 F). Despite a $50 \mathrm{~dB}$ elevation of threshold SPL in TR $\beta^{-1-}$ mice, the waveform of the CAP and summating potential (SP) signal recorded at the round window for $11.3 \mathrm{kHz}$ tone bursts were normal (Zidanic and Brownell, 1992) (Fig. 2G), indicating that action potentials were generated in the auditory nerve and transmitted to the brainstem. However, the increased slopes of the CAP input-output functions in TR $\beta^{-1-}$ mice (Fig. $2 F$ ) point to recruitment and dysfunction of cochlear amplification.
Deafness of $\operatorname{TR} \beta^{-/-}$mice is correlated with severe reduction in mechanical performance

To test outer hair cell performance, cochlear microphonics (CM) were analyzed from CM input-output functions in 2-month-old TR $\beta$-Ctr and TR $\beta^{-/-}$mice. A severe reduction of CM was noted in $\operatorname{TR} \beta^{-1-}$ mice (Fig. $3 A$ ). CM input-output functions at $4 \mathrm{kHz}$ indicated a threshold elevation from 60 to $90 \mathrm{~dB}$ SPL; at $100 \mathrm{~dB}$ SPL CM amplitudes were reduced by $20 \mathrm{~dB}$ (Fig. 3A). In addition, distortion product otoacoustic emission (DPOAE) thresholds, measured as a function of f2-frequency at various frequencies, were altered. In TR $\beta^{-1-}$ mutants, no $2 \mathrm{f} 1-\mathrm{f} 2 \mathrm{am}-$ plitudes baseline was detected using f2-frequency of $16 \mathrm{kHz}$ 
(Fig. $3 B$ ), and significantly elevated $2 \mathrm{f} 1-\mathrm{f} 2$ thresholds $>8 \mathrm{kHz}$ were observed (Fig. 3C), supporting the notion of impaired $\mathrm{OHC}$ function. This was surprising since $\mathrm{TR} \beta$ mutation was hypothesized to affect inner rather than outer hair cell function as previous studies indicated normal endocochlear potentials, OHC mechanotransducer currents and nonlinear capacitances (Rüsch et al., 1998).

Because hypothyroidism has been shown to cause malformation of the TM (Uziel, 1986), we re-examined TM morphology using an epoxy resin embedding approach. Considerable structural abnormalities of the TM were observed in 2 -month-old TR $\beta^{-l-}$ mice (Fig. $3 F, I$ ) compared with TR $\beta$ Ctr (Fig. $3 D, G)$ and HC-TR $\beta^{-1-}$ mice (Fig. $3 E, H$ ). Obvious thickening and enlargement of the TM (Fig. $3 F, I, J-L$, thickness, area, highlighted in gray) were verified by measuring $20-60$ cross-sections of apical, medial, and midbasal cochlear turns from two TR $\beta$-Ctr, $\mathrm{HC}-\mathrm{TR} \beta^{-1-}$, and $\operatorname{TR} \beta^{-1-}$ mice, respectively. Both thickening and enlargement of the TM in $\operatorname{TR} \beta^{-1-}$ mice were most prominent in the apical turns. Furthermore, the enlarged TM showed an increased $\alpha$ - and $\beta$-tectorin immunolabeling. There was an obvious increase in $\alpha$-tectorin (Fig. $4 A-D$ ) and $\beta$-tectorin immunoreactivity (Fig. $4 E-H)$ along the entire tonotopic axis, which was found in 3 (of 3 ) different specimens of 4- to 5-month-old TR $\beta^{-1-}$ mice. For quantification of $\alpha$ - and $\beta$-tectorin levels, Western blotting and densitometric analysis were performed using dissected cochlear tissue. The intensities of $\alpha$ - and $\beta$-tectorin were normalized to the level of the codetected house keeping protein ezrin (Fig. $4 I, J$ ), yielding an increase to $180 \pm 27 \%$ for $\alpha$-tectorin (Fig. $4 I$ ) and $147 \pm 15 \%$ for $\beta$-tectorin (Fig. $4 J$ ) in $\operatorname{TR} \beta^{-1-}$ mice relative to $\operatorname{TR} \beta$-Ctr mice.

\section{Discussion}

In the present study, hair cell-specific deletion of the TR $\beta$ gene after P11 is shown to delay BK current expression in $\mathrm{HC}-\mathrm{TR} \beta^{-1-}$ IHCs, similar as in constitutive TR $\beta^{-/-}$mutants (Rüsch et al., 1998). Nevertheless, HC-TR $\beta^{-1-}$ mice developed normal hearing, indicating (1) a dispensable role of BK for basic hearing function, and (2) a negligible role of $\operatorname{TR} \beta$ after onset of hearing. The finding that $\mathrm{TR} \beta^{-1-}$ IHCs show normal $\mathrm{Ca}^{2+}$ currents and normal maturation of exocytosis at P20 suggests that maturation of exocytosis efficiency, recently shown to require TH (Brandt et al., 2007), proceeds independently of TR $\beta$. Indeed, evidence is increasing that in addition to $\operatorname{TR} \beta$, liganded $\operatorname{TR} \alpha 1$ also plays a role for development of many organs (Flamant and Samarut, 2003; Quignodon et al., 2007) including the cochlea (Winter et al., 2006, 2007).

Normal shape of the CAP response waveform in $\mathrm{TR} \beta^{-1-}$ mice despite up to $50 \mathrm{~dB}$ threshold elevation implies normal exocytotic function of IHCs. The elevated thresholds most likely reflect a loss of sensitivity because of impaired mechanical performance of the organ of Corti. Normal exocytosis and shape of the CAP waveform show that action potentials are generated in the auditory nerve and transduced to the brainstem in $\operatorname{TR} \beta^{-1-}$ mice. However, we cannot exclude that lack of TR $\beta$ activity in central auditory nuclei before P11 contributes to hearing loss in $\mathrm{TR} \beta^{-1-}$ mice. Considering normal endocochlear potential and OHC nonlinear capacitance in TR $\beta^{-1-}$ mutants (Rüsch et al., 1998), their reduced DPOAEs and CM shown here are expected to arise from improper mechanical excitation of OHCs. Malformation of the TM has been described in hypothyroidism (Deol, 1973; Uziel, 1986) and was observed in TR $\alpha 1^{-1-} \beta^{-1-}$ double mutants (Rusch et al., 2001). So far, abnormalities have not been
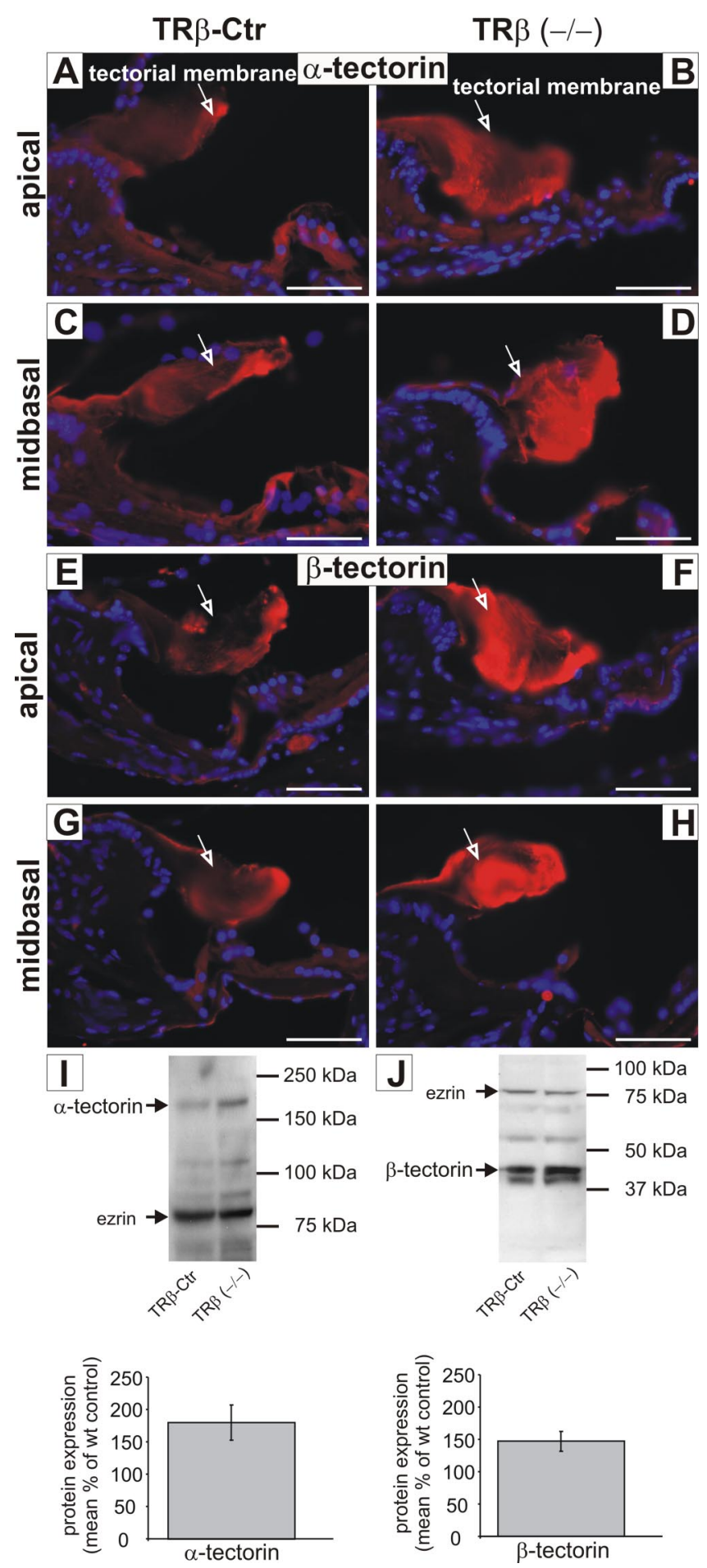

Figure 4. $\alpha$ - and $\beta$-tectorin in $\operatorname{TR} \beta$-Ctr and $\operatorname{TR} \beta^{-/-}$mice. $\boldsymbol{A}-\boldsymbol{H}$, Immunohistochemistry against $\alpha$-tectorin $(\boldsymbol{A}-\boldsymbol{D}$, red) and $\beta$-tectorin ( $\boldsymbol{E}-\boldsymbol{H}$, red) shows a more abundant expression in $\operatorname{TR} \beta^{-I-}$ compared with TR $\beta$-Ctr mice. Nuclei are stained in blue with DAPI. Scale bars, $20 \mu \mathrm{m}$. I, J, Western blots and densitometric quantification of $\alpha$-tectorin $(\boldsymbol{I})$ and $\beta$-tectorin expression levels $(\boldsymbol{J})$ in $\operatorname{TR} \beta^{-1-}$ mice compared with TR $\beta$-Ctr animals. The house keeping protein ezrin was used for normalization. Data are expressed as mean percentage of control \pm SD.

observed in light microscopic analyses of $\mathrm{TR} \beta^{-1-}$ animals (Forrest et al., 1996; Rusch et al., 2001) probably because specimens were analyzed at around P20.

In humans, a mild auditory phenotype is associated with heterozygosity for mutations in the THRB gene that reduce T3- 
binding capacity and cause the autosomal dominant disorder RTH (Brucker-Davis et al., 1996). Analysis of a homologous knock-in mouse model for RTH that segregates the orthologue of a well characterized human RTH mutation revealed profound hearing impairment at all tested frequencies associated with normal structure of the basilar membrane and stria vascularis but severe abnormalities of the TM (Griffith et al., 2002). Similar to our present findings, Griffith et al. (2002) showed a significant thickening of the TM.

There is no doubt that an intact TM is required for proper deflection of OHC stereocilia (Gummer et al., 1996). Missense mutations of one of the major TM proteins, $\alpha$-tectorin (Legan et al., 2000), leads to autosomal dominant nonsyndromic hearing impairment (Verhoeven et al., 1998; Mustapha et al., 1999). The mouse model Tecta ${ }^{-1-}$ displays complete detachment of the TM and impaired hearing thresholds as OHCs cannot effectively respond to basilar membrane motion (Legan et al., 2000).

In TR $\beta^{-1-}$ mutants, the detachment of the TM from the cells of the greater epithelial ridge (GER) is delayed for days, and in $\mathrm{TR} \alpha 1^{-/-} \beta^{-1-}$ double mutants, it can be delayed for weeks (Rusch et al., 2001). In conclusion, we suggest that a delay in reshaping the GER in TR $\beta^{-/-}$mutants disturbs the correct timing of TM secretion (Rau et al., 1999) resulting in a likely prolonged secretion of tectorins and a pathological TM mass. According to recent findings for $\beta$-tectorin, changes in TM mass may directly alter cochlear microphonics (Russell et al., 2007).

\section{References}

Beutner D, Moser T (2001) The presynaptic function of mouse cochlear inner hair cells during development of hearing. J Neurosci 21:4593-4599.

Bradley DJ, Towle HC, Young WS 3rd (1994) $\alpha$ and $\beta$ thyroid hormone receptor (TR) gene expression during auditory neurogenesis: evidence for TR isoform-specific transcriptional regulation in vivo. Proc Natl Acad Sci U S A 91:439-443.

Brandt N, Kuhn S, Münkner S, Braig C, Winter H, Blin N, Vonthein R, Knipper M, Engel J (2007) Thyroid hormone deficiency affects postnatal spiking activity and expression of $\mathrm{Ca}^{2+}$ and $\mathrm{K}^{+}$channels in rodent inner hair cells. J Neurosci 27:3174-3186.

Brucker-Davis F, Skarulis MC, Pikus A, Ishizawar D, Mastroianni MA, Koby M, Weintraub BD (1996) Prevalence and mechanisms of hearing loss in patients with resistance to thyroid hormone. J Clin Endocrinol Metab 81:2768-2772.

Deol MS (1973) An experimental approach to the understanding and treatment of hereditary syndromes with congenital deafness and hypothyroidism. J Med Genet 10:235-242.

Dulon D, Sugasawa M, Blanchet C, Erostegui C (1995) Direct measurements of $\mathrm{Ca}^{2+}$-activated $\mathrm{K}^{+}$currents in inner hair cells of the guinea-pig cochlea using photolabile $\mathrm{Ca}^{2+}$ chelators. Pflugers Arch 430:365-373.

Flamant F, Samarut J (2003) Thyroid hormone receptors: lessons from knockout and knock-in mutant mice. Trends Endocrinol Metab 14:85-90.

Forrest D (1996) Deafness and goiter: molecular genetic considerations. J Clin Endocrinol Metab 81:2764-2767.

Forrest D, Erway LC, Ng L, Altschuler R, Curran T (1996) Thyroid hormone receptor $\beta$ is essential for development of auditory function. Nat Genet 13:354-357.

Griffith AJ, Szymko YM, Kaneshige M, Quiñónez RE, Kaneshige K, Heintz KA, Mastroianni MA, Kelley MW, Cheng SY (2002) Knock-in mouse model for resistance to thyroid hormone (RTH): an RTH mutation in the thyroid hormone receptor $\beta$ gene disrupts cochlear morphogenesis. J Assoc Res Otolaryngol 3:279-288.

Gummer AW, Hemmert W, Zenner HP (1996) Resonant tectorial membrane motion in the inner ear: its crucial role in frequency tuning. Proc Natl Acad Sci U S A 93:8727-8732.

Johnson SL, Marcotti W, Kros CJ (2005) Increase in efficiency and reduc- tion in $\mathrm{Ca}^{2+}$ dependence of exocytosis during development of mouse inner hair cells. J Physiol 563:177-191.

Keiler S, Richter CP (2001) Cochlear dimensions obtained in hemicochleae of four different strains of mice: CBA/CaJ, 129/CD1, 129/SvEv and C57BL/6J. Hear Res 162:91-104.

Knipper M, Zinn C, Maier H, Praetorius M, Rohbock K, Köpschall I, Zimmermann U (2000) Thyroid hormone deficiency before the onset of hearing causes irreversible damage to peripheral and central auditory systems. J Neurophysiol 83:3101-3112.

Knipper M, Richardson G, Mack A, Müller M, Goodyear R, Limberger A, Rohbock K, Köpschall I, Zenner HP, Zimmermann U (2001) Thyroid hormone-deficient period prior to the onset of hearing is associated with reduced levels of $\beta$-tectorin protein in the tectorial membrane: implication for hearing loss. J Biol Chem 276:39046-39052.

Kros CJ, Ruppersberg JP, Rüsch A (1998) Expression of a potassium current in inner hair cells during development of hearing in mice. Nature 394:281-284.

Legan PK, Lukashkina VA, Goodyear RJ, Kössi M, Russell IJ, Richardson GP (2000) A targeted deletion in $\alpha$-tectorin reveals that the tectorial membrane is required for the gain and timing of cochlear feedback. Neuron 28:273-285.

Müller M, Smolders JW, Meyer zum Gottesberge AM, Reuter A, Zwacka RM, Weiher H, Klinke R (1997) Loss of auditory function in transgenic Mpv17-deficient mice. Hear Res 114:259-263.

Mustapha M, Weil D, Chardenoux S, Elias S, El-Zir E, Beckmann JS, Loiselet J, Petit C (1999) An $\alpha$-tectorin gene defect causes a newly identified autosomal recessive form of sensorineural pre-lingual non-syndromic deafness, DFNB21. Hum Mol Genet 8:409-412.

Ng L, Rüsch A, Amma LL, Nordström K, Erway LC, Vennström B, Forrest D (2001) Suppression of the deafness and thyroid dysfunction in Thrb-null mice by an independent mutation in the Thra thyroid hormone receptor $\alpha$ gene. Hum Mol Genet 10:2701-2708.

Pyott SJ, Meredith AL, Fodor AA, Vázquez AE, Yamoah EN, Aldrich RW (2007) Cochlear function in mice lacking the BK channel $\alpha, \beta 1$, or $\beta 4$ subunits. J Biol Chem 282:3312-3324.

Quignodon L, Vincent S, Winter H, Samarut J, Flamant F (2007) A point mutation in the activation function 2 domain of thyroid hormone receptor $\alpha 1$ expressed after CRE-mediated recombination partially recapitulates hypothyroidism. Mol Endocrinol 21:2350-2360.

Rau A, Legan PK, Richardson GP (1999) Tectorin mRNA expression is spatially and temporally restricted during mouse inner ear development. J Comp Neurol 405:271-280.

Refetoff S, Dumitrescu AM (2007) Syndromes of reduced sensitivity to thyroid hormone: genetic defects in hormone receptors, cell transporters and deiodination. Best Pract Res Clin Endocrinol Metab 21:277-305.

Rüsch A, Erway LC, Oliver D, Vennström B, Forrest D (1998) Thyroid hormone receptor $\beta$-dependent expression of a potassium conductance in inner hair cells at the onset of hearing. Proc Natl Acad Sci U S A 95:15758-15762.

Rusch A, Ng L, Goodyear R, Oliver D, Lisoukov I, Vennstrom B, Richardson G, Kelley MW, Forrest D (2001) Retardation of cochlear maturation and impaired hair cell function caused by deletion of all known thyroid hormone receptors. J Neurosci 21:9792-9800.

Russell IJ, Legan PK, Lukashkina VA, Lukashkin AN, Goodyear RJ, Richardson GP (2007) Sharpened cochlear tuning in a mouse with a genetically modified tectorial membrane. Nat Neurosci 10:215-223.

Rüttiger L, Sausbier M, Zimmermann U, Winter H, Braig C, Engel J, Knirsch M, Arntz C, Langer P, Hirt B, Müller M, Köpschall I, Pfister M, Münkner S, Rohbock K, Pfaff I, Rüsch A, Ruth P, Knipper M (2004) Deletion of the $\mathrm{Ca}^{2+}$-activated potassium (BK) $\alpha$-subunit but not the BK $\beta 1$-subunit leads to progressive hearing loss. Proc Natl Acad Sci USA 101: 12922-12927.

Sap J, Muñoz A, Damm K, Goldberg Y, Ghysdael J, Leutz A, Beug H, Vennström B (1986) The c-erb-A protein is a high-affinity receptor for thyroid hormone. Nature 324:635-640.

Schug N, Braig C, Zimmermann U, Engel J, Winter H, Ruth P, Blin N, Pfister M, Kalbacher H, Knipper M (2006) Differential expression of otoferlin in brain, vestibular system, immature and mature cochlea of the rat. Eur J Neurosci 24:3372-3380.

Tian Y, Li M, Fritzsch B, Zuo J (2004) Creation of a transgenic mouse for hair-cell gene targeting by using a modified bacterial artificial chromosome containing Prestin. Dev Dyn 231:199-203. 
Uziel A (1986) Periods of sensitivity to thyroid hormone during the development of the organ of Corti. Acta Otolaryngol Suppl 429:23-27.

Verhoeven K, Van Laer L, Kirschhofer K, Legan PK, Hughes DC, Schatteman I, Verstreken M, Van Hauwe P, Coucke P, Chen A, Smith RJ, Somers T, Offeciers FE, Van de Heyning P, Richardson GP, Wachtler F, Kimberling WJ, Willems PJ, Govaerts PJ, Van Camp G (1998) Mutations in the human $\alpha$-tectorin gene cause autosomal dominant non-syndromic hearing impairment. Nat Genet 19:60-62.

Weinberger C, Thompson CC, Ong ES, Lebo R, Gruol DJ, Evans RM (1986) The c-erb-A gene encodes a thyroid hormone receptor. Nature 324:641-646.

Weiss RE, Refetoff S (2000) Resistance to thyroid hormone. Rev Endocr Metab Disord 1:97-108.
Winter H, Braig C, Zimmermann U, Geisler HS, Fränzer JT, Weber T, Ley M, Engel J, Knirsch M, Bauer K, Christ S, Walsh EJ, McGee J, Köpschall I, Rohbock K, Knipper M (2006) Thyroid hormone receptors $\operatorname{TR} \alpha 1$ and $\operatorname{TR} \beta$ differentially regulate gene expression of Kcnq4 and prestin during final differentiation of outer hair cells. J Cell Sci 119:2975-2984.

Winter H, Braig C, Zimmermann U, Engel J, Rohbock K, Knipper M (2007) Thyroid hormone receptor $\alpha 1$ is a critical regulator for the expression of ion channels during final differentiation of outer hair cells. Histochem Cell Biol 128:65-75.

Zidanic M, Brownell WE (1992) Fine structure of the intracochlear potential field. II. Tone-evoked waveforms and cochlear microphonics. J Neurophysiol 67:108-124. 